\title{
PV Panel Sıcaklığı Üzerinde Etkili Olan Atmosferik Parametrelerin Araştırılması
}

\author{
Investigation of Atmospheric Parameters Affecting PV Panel Temperature
}

\author{
Mustafa ATMACA ${ }^{1}$ (D), İmdat Zafer PEKTEMİ² \\ ${ }^{1}$ Marmara Üniversitesi, Teknoloji Fakültesi, Makine Mühendisliği Bölümü \\ ${ }^{2}$ Konya Çevre ve Şehircilik Il Müdürlüğ̈̈
}

$\ddot{O} z$

Enerji kaynakları çok sınırlı. Diğer taraftan, fosil yakıtlar kirletici emisyonlara neden olmakta ve fosil yakıtların olumsuz etkileri gün geçtikçe artmaktadır. Bu nedenle, fosil yakıtların artan olumsuz etkileri doğal çevreyi tehdit etmektedir. Şu bir gerçektir ki, sürdürülebilirlik, enerji kaynakları yenilenebilir olduğunda sağlanabilmektedir. Bir başka deyişle, sürdürülebilir bir yaşam için, yenilenebilir enerjinin kullanılması kaçınılmaz bir olgudur.

Yenilenebilir enerji kaynaklarından yararlanmanın en pratik yollarından birisi ise, PV (fotovoltaik) panellerin kullanımıdır. Güneş enerjisinden elektrik üreten bu panellerin sıcaklığı, elektrik üretimi yaparken yükselmektedir. Bu problemin çözümü, PV panellerin verimli kullanımı için çok önemlidir. Artan sıcaklık probleminin çözümü için ilk adım ise, panel sıcaklığı üzerinde etkili olan atmosferik parametrelerin belirlenmesidir. Bu çalışmada, değişik iklimsel koşullar altında, PV panel sıcaklığının nasıl değiştiği araştırılmıştır. Bu amaçla, bir PV sistem dizayn edilmiş ve PV panel sıcaklığının ölçülmesi için, bir sıcaklık sensörü PV panelin merkezine yerleştirilmiştir. Çalışma farklı iklim koşullarına sahip günlerde yürütülmüş olup, atmosferik parametreler ölçülmüştür. Diğer taraftan, elde edilen veriler, bu konuda yapılmış diğer çalışmaların verileri ile karşılaştırılmıştır. Sonuçlar, güneş radyasyonu, hava sıcaklığı ve rüzgar hızının panel sıcaklığı üzerinde çok etkili faktörler olduğunu göstermektedir. Özellikle, rüzgar hızı PV panel sıcaklığının belirlenmesinde mutlaka hesaba katılmalıdır.

Anahtar kelimeler: Güneş 1şınımı, çevre sıcaklığı, rüzgar hızı, PV panel sıcaklığı

\begin{abstract}
Energy sources are very limited. On the other hand, fossil fuels cause polluting emissions and their negative effects are increasing day by day. Therefore, increased negative effects of fossil fuels threatened the natural environment. It is reality that sustainability is possible when energy sources are renewable. In other words, usage of renewable energy sources is inevitable fact for a sustainable life.

One of the most practical ways of gained renewable energy is usage of PV (photovoltaic) panels. The temperature of these panels which produce electricity from solar energy increases during electricity production. Solving of this problem is very important for efficient usage of the PV panels. First step of solving of increased temperature problem is determine to effective atmospheric parameters on the PV panel temperature. In this study, the PV panel temperature was investigated under different climatic conditions. For this purpose a PV system was designed and a temperature sensor was placed on the center of the panel for measure of PV panel temperature. Study was conducted on several days which had different climatic conditions and atmospheric parameters were measured. On the other hand, results were compared with other studies about this issue. Results show that solar irridation, ambient temperature and wind speed are very effective factors on the PV panel temperature. Particularly, wind speed should be consider for determine of the PV panel temperature.
\end{abstract}

Keywords: Solar irridance, ambient temperature, wind speed, PV panel temperature

\section{I.GíRISs}

PV paneller, güneş ışılnlarından elektrik üretimine olanak sağlarlar. Ama elektrik üretimi yaparken panellerin sıcaklığı yükselir. $\mathrm{Bu}$ yüzden panelin elektriksel verimi düşer. Kalogirou and Tripanagnostopoulos [1] çalışmalarında; verim düşümü problemi hakkında aşağıdaki saptamayı yapmışlardır.

Monokristal (c-Si) ve polikristal ( pc-Si ) silikon güneş hücreleri için verim düşüşü, her bir derece sicaklik artışında, yaklaşık $0,45 \%$ dir. Amorf silikon güneş hücreleri için, bu etki daha düşük olup her bir derece için, yaklaşık $0,25 \% \operatorname{dir}[1]$. 
Ayrıca PV panel sıcaklığının belirlenmesi, PV/T (fotovoltaik-termal) sistem çalışmalarında önemlidir. Fotovoltaik-termal (PV/T) sistemler, artan PV panel sıcaklığını düşürmesinin yanısıra, farklı şekillerde enerji dönüşümlerine olanak sağlarlar. Bu sistemlerin başlıcaları, hava esaslı ve su esaslı sistemlerdir [2].

Diğer taraftan, bu çalışmalar arasında iki akışkanlı fotovoltaik-termal sistem çalışmaları vardır. Örneğin, Atmaca M. ve arkadaşları [3], bir PV/T sistem sayesinde aynı güneş panelinden 1sıtma, sıcak su ve elektrik elde etmenin mümkün olduğunu göstermişlerdir.

Ayrıca artan sıcaklık probleminin çözümü, PV panellerin verimli kullanımı için çok önemlidir ve sıcaklık artışı probleminin çözümünde ilk adım, PV panel sicaklığı üzerinde etkili olan atmosferik parametrelerin belirlenmesidir. $\mathrm{Bu}$ konuda çeşitli çalışmalar yapılmıştır. Bunlardan birisi Bardhi ve arkadaşlarının [4] yaptığı çalışmadır. Çalışma sonuçlarına göre; radyatif terimin ihmali halinde PV panel sıcaklığı, düşük güneş 1şınımı seviyelerinde fazla hesaplanmış, yüksek güneş 1şınımı seviyelerinde ise düşük hesaplanmış olur.

Ayrıca, Lasnier ve Ang [5], polikristal PV modullerde gerçekleşen, panel sıcaklığı için aşağıdaki formülü önermişlerdir. (Burada G: güneş 1şınımı, Ta ise ortam sıcaklığıdır.)

$\mathrm{TPV}=30+0.0175(\mathrm{G}-300)+1.14(\mathrm{Ta}-25)$

Bir başka çalışmada, Muzathik A.M. [6] PV panel sıcaklığının belirlenmesi için, rüzgar hızının da hesaba katıldığı aşağıdaki eşitliği ortaya koymuştur. Burada $\mathrm{T}_{\text {ambiant; }}$ ortam sıcaklığını $\left({ }^{\circ} \mathrm{C}\right)$, Irridance; 1 şınım miktarını $\left(\mathrm{W} / \mathrm{m}^{2}\right)$, wind speed ise rüzgar hızını $(\mathrm{m} / \mathrm{s})$ göstermektedir.
$\mathrm{T}_{\text {module }}\left({ }^{\circ} \mathrm{C}\right)$

$=0.943 \times \mathrm{T}_{\text {ambiant }}+0.0195 \times$ Irridance $-1.528 \times$ Wind speed +0.3529

İşletme sıcaklığı, fotovoltaik dönüşüm süreçlerinde önemli bir rol oynar [7]. Bu çalışmada, farklı iklimsel koşullarda, atmosferik parametrelerin PV panel sıcaklığını nasıl etkilediği araştırılmıştır. Ayrıca, bu atmosferik parametrelere bağlı olarak, gövde sıcaklığının, nasıl bir eğilim gösterdiği şekillerle açıklanmıştır. Bu amaçla, Türkiye' de Konya İli' nde bir fotovoltaik sistem tasarlanmış ve $33^{\circ}$ eğimle monte edilmiştir. Çalışma, farklı iklimsel koşullarda yürütülmüş ve bu koşullarda PV panel sıcaklığının nasıl değiştiği belirlenmiştir. Ayrıca sonuçlar, Muzathik [6] ve Lasnier ve Ang' in [5] çalışma sonuçları ile karşılaştırılmıştır. Çalışma, PV panel sıcaklığı ile atmosferik parametrelerin eşzamanlı değişimini inceleyerek ve farklı çalışma sonuçları ile karşılaştırmalar yaparak, bu konuda yapılacak araştırma ve montaj süreçlerine 1 şı tutmayı hedeflemektedir.

\section{II.MATERYAL VE YÖNTEM}

\subsection{Sistemin Tanımı}

Şekil 1'de deney tesisatı ve Tablo 1'de, özellikleri verilen sensörlerin yerleşimi, şematik olarak gösterilmiştir. PV panel, köşegen profilden imal edilmiş modül platformu üzerine, doğrudan yerleştirilmiştir. Deney tesisatı elektriksel devresine ait ekipmanlar; elektriksel devre, inverter, şarj kontrol cihazı, akü ve kesici pano, temel ekipmanlar olmak üzere, bunlara bağlı donanımlardan oluşmaktadır. İnverterler, şarj kontrol cihazları ve kesici anahtarlar, bir kumanda panosu içerisine monte edilmiştir.

Piranometre ile ışınım değerleri ölçülmüş olup, PV paneliyle aynı açıda $\left(33^{\circ}\right)$ yerleştirilmiştir. Rüzgar hızını ölçen sensör ise, PV panelin üst kenarı seviyesine yerleştirilmiştir. Şekil 1 ile ilgili diğer detaylar, Tablo 1 'de verilmiştir.

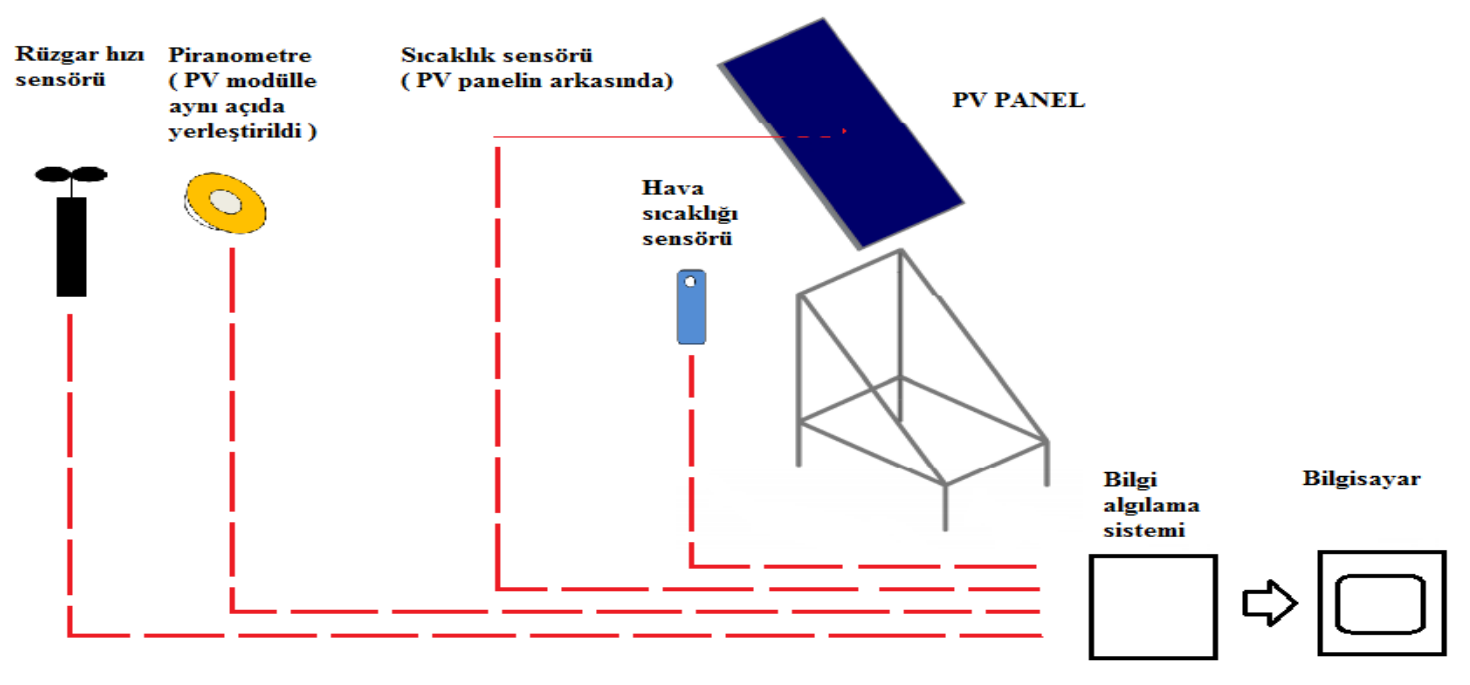

Şekil 1. Deney düzeneği ve sensör yerleşimi $[8,9,10]$ 
Tablo 1. Sensör özellikleri

\begin{tabular}{|c|c|c|c|}
\hline No & Sensör tipi & Yerleştirme şekli & Özellikleri \\
\hline $\mathbf{1}$ & Sicaklık sensörü & $\begin{array}{c}\text { PV panelin arka yüzünün ortasına } \\
\text { yerleştirilmiştir. }\end{array}$ & Pt 100 \\
\hline $\mathbf{3}$ & Piranometre & $\begin{array}{c}33^{\circ} \text { eğim açısıyla yerleştirl- } \\
\text { ilmiştir. }\end{array}$ & $\begin{array}{c}\text { EKO MS- } 410 \text { Hassasiyet:11.78 } \mu \mathrm{V} / \mathrm{Wm}-2,0- \\
2000 \mathrm{~W} / \mathrm{m}^{2}\end{array}$ \\
\hline $\mathbf{4}$ & Hava sıcaklığı sensörü & $\begin{array}{c}\text { Direkt güneş 1şınlarına maruz } \\
\text { kalmayacak şekilde,1m } \\
\text { yüksekliğe ve yerleştirilmiştir. } \\
\text { PV panel üst seviyesine } \\
\text { yerleştirilmiştir. }\end{array}$ & NTC $10 \mathrm{~K}$ \\
\hline $\mathbf{5}$ & Rüzgar hizı sensörü & $\begin{array}{c}3 \text { armed cup anemometer } \\
\text { Hall sensor array }\end{array}$ \\
\hline
\end{tabular}

\section{ANALIZ}

Çalışma farklı iklimsel koşullara sahip günlerde yürütülmüştür. Bu günler; 24 Şubat, 10 Mart, 11 Mart, 22 Nisan, 28 Nisan, 29 Nisan ve 1 Temmuz günleridir. İlk altı gün rüzgarlı günler olmakla birlikte, 1 Temmuz sakin bir gündür. Ele alınan günlerde, hava sıcaklığı 10 ${ }^{\circ} \mathrm{C}$ ile $40{ }^{\circ} \mathrm{C}$ arasında değişmektedir. Ayrıca PV panel gövde sıcaklığının; güneş 1şınımı, hava sıcaklığı ve rüzgar hızına bağlı olduğunu ve güneş 1şınımı arttığında PV panel gövde sicaklığının arttığını aşağıdaki şekillerden kolaylıkla görebiliriz (Şekil 2Şekil 8). Özellikle, güneş 1şınları bulutlar tarafindan engellendiğinde, güneş 1şınımında keskin düşüşler görülmektedir. $\mathrm{Bu}$ düşüş anlarında, $\mathrm{PV}$ panel sıcaklığındaki düşüşleri Şekil 2, Şekil 4 ve Şekil 8'de belirgin olarak görebiliriz. Ayrıca, maksimum PV panel sıcaklığı, 1 Temmuz tarihinde gerçekleşmiştir çünkü, 1 Temmuzda hava sıcaklığı oldukça yüksektir ve rüzgar yoktur.

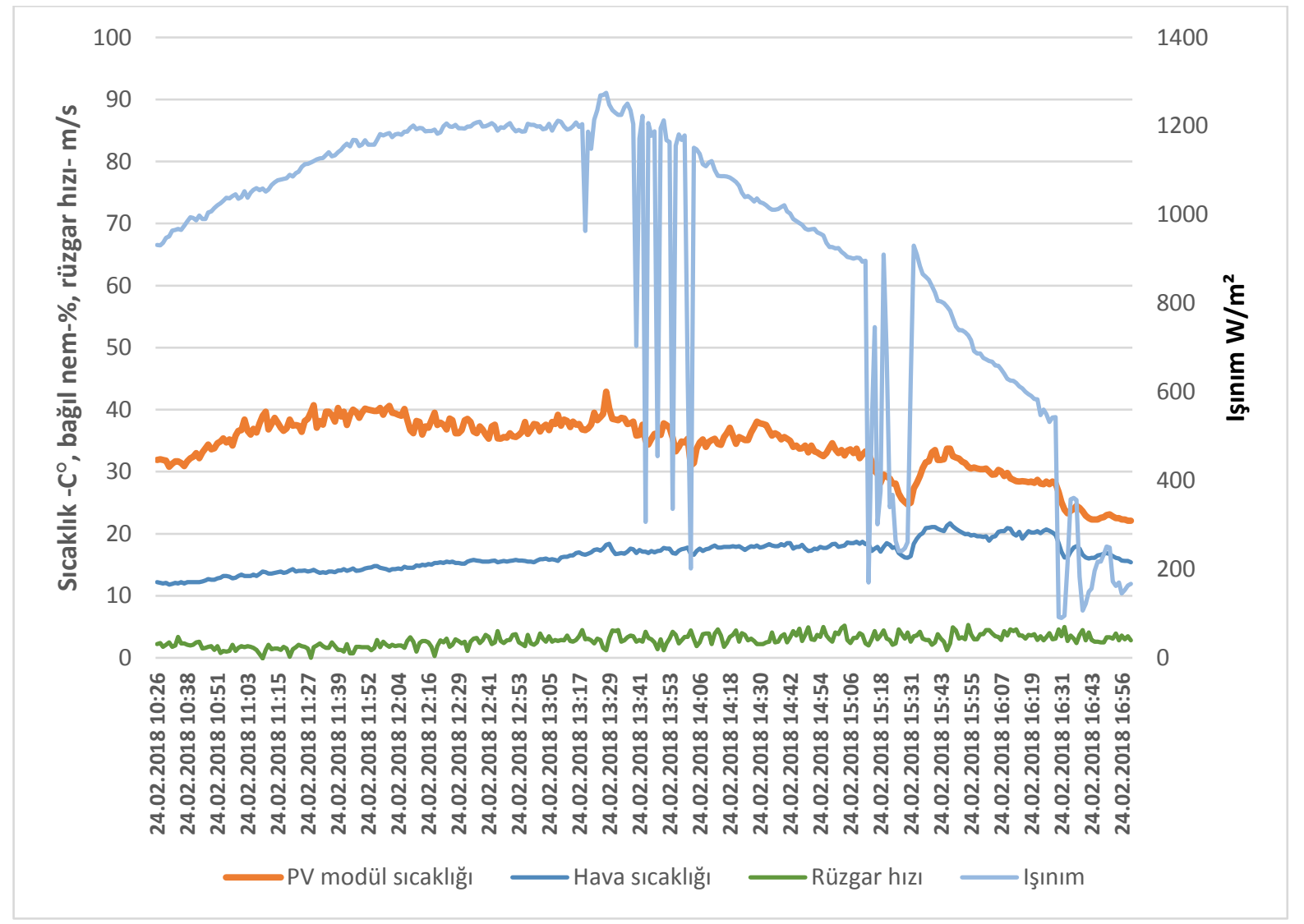

Şekil 2. 24. 02.2018 tarihindeki temel parametreler. 


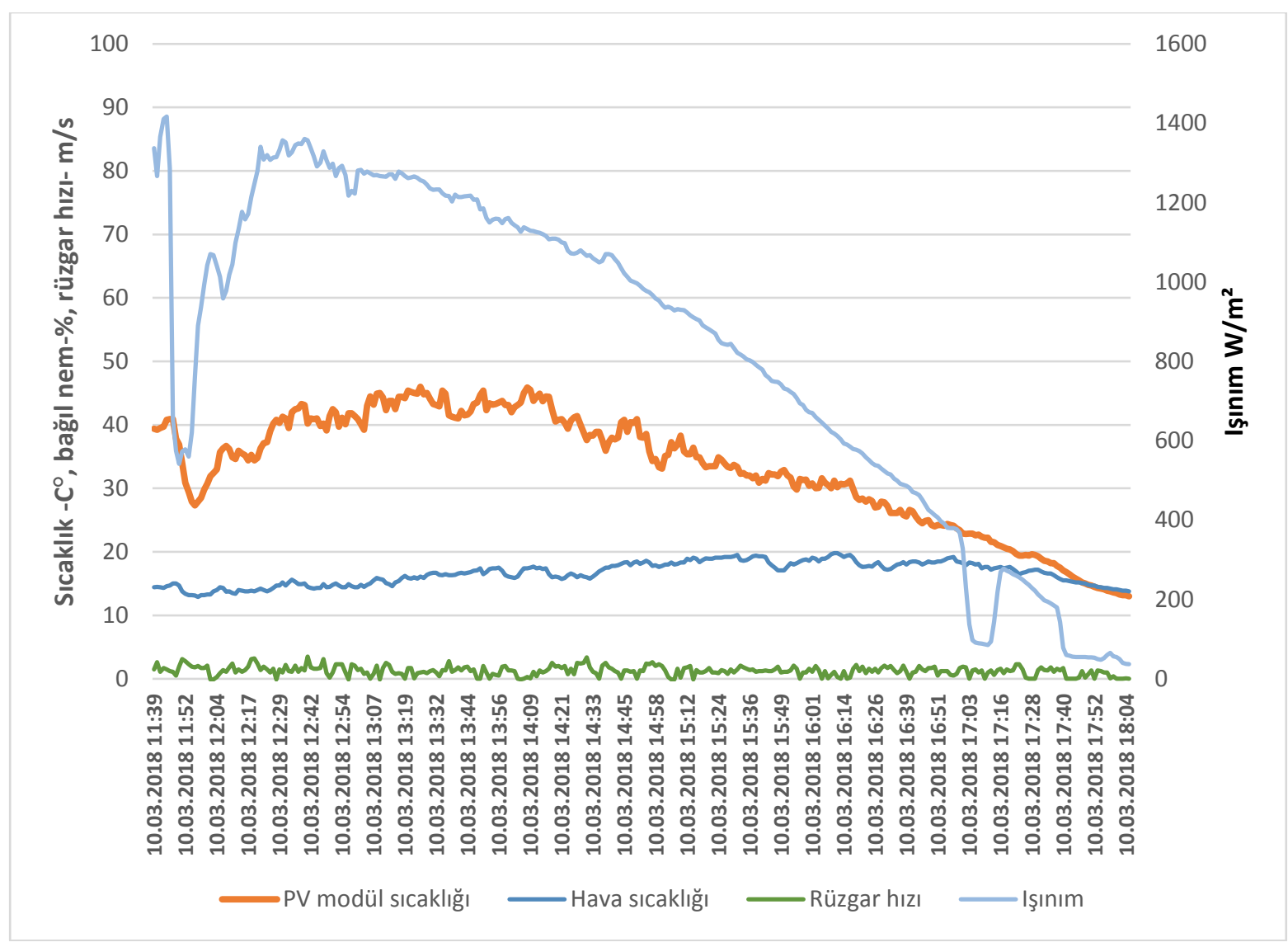

Şekil 3.10.03.2018 tarihindeki temel parametreler.

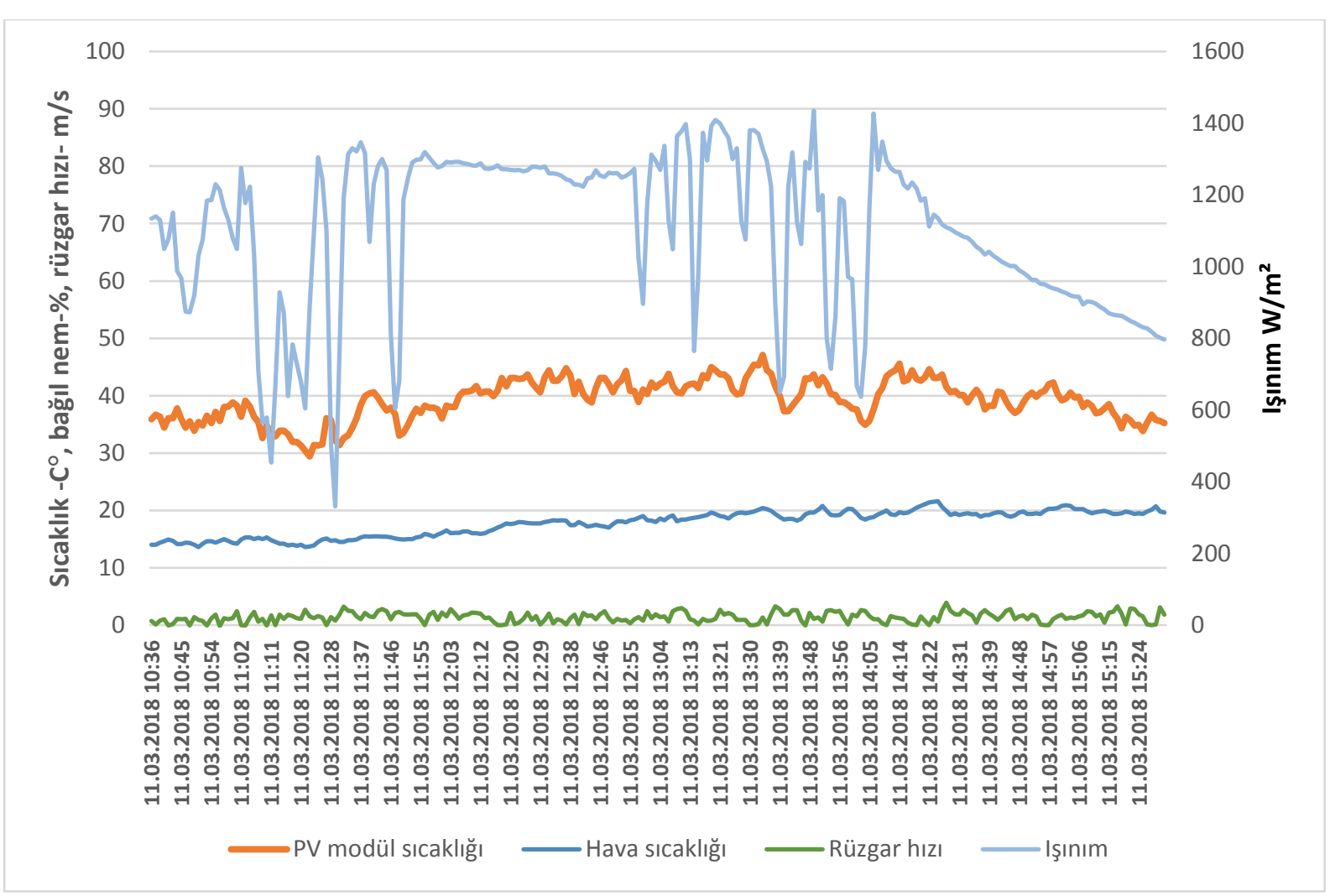

Şekil 4. 11.03.2018 tarihindeki temel parametreler. 
Şekil 2 Şekil 3 ve Şekil 4' ten kolayca anlaşılacağ üzere, güneş radyasyonu değerinin artması ve azalması modül sıcaklıklarını doğrudan etkilemektedir. Işınımın yüksek olduğu zaman dilimlerinde, modül sıcaklılarının yükseldiğini, 1şınımın azaldığı zaman dilimlerinde de modül sicaklıklarının azaldığ görülmektedir. Ayrıca rüzgar hızının artması ve azalması modül sıcaklıklarını doğrudan etkilemektedir. Şekil 3'te 10 Mart gününe ait temel atmosferik parametrelerin ve gövde sıcaklığının değişimi görülmektedir. $\mathrm{Bu}$ şekilde, 11:53 civarında, bulutlanmaya bağlı olarak güneş 1şınımındaki keskin düşüşü görebiliriz. Bu keskin düşüşe bağlı olarak da PV panel gövde sıcaklığı, $40{ }^{\circ} \mathrm{C}$ civarından $30{ }^{\circ} \mathrm{C}$ civarına düşüş göstermiştir. Yine 24 Şubat günündeki değişim, Şekil 2'de, 11 Mart günündeki değişim, Şekil 4'te görülmektedir. Yine bu şekillerde, güneş 1şınımına bağlı olarak, PV panel gövde sıcaklığının değiştiği görülmektedir. Diğer taraftan, rüzgar hızındaki değişimin, PV panel gövde sıcaklığını etkilediğini Şekil 2'de gösterilen 24 Şubat gününde ait grafik ile Şekil 3'te gösterilen, 10 Mart gününe ait grafiği karşılaştırarak görebiliriz. Her iki günde de, hava sıcaklığı yaklaşık $10 \quad{ }^{\circ} \mathrm{C}$ ile $20{ }^{\circ} \mathrm{C}$ aralığında gerçekleşmiştir. Fakat rüzgar hızı 24 Şubat günü, 10 Mart gününe göre daha yüksek bir seyir izlemiştir ve özellikle her iki günde de, saat 12:30-13:30 aralığında 1şınım değerleri birbirine yakındır fakat rüzgar hızı 24 Şubat günü, 10 Mart gününe göre daha yüksektir. Bu sebeple de, PV panel gövde sıcaklığı, 24 Şubat günü, belirtilen zaman aralığında, $40{ }^{\circ} \mathrm{C}$ civarında değişirken, 10 Mart günü $45^{\circ} \mathrm{C}$ değerine çıkmıştır. Ayrıca hava sıcaklığı, Şekil 2, Şekil 3, Şekil 4 ve Şekil 5'te gösterildiği üzere, 24 Şubat, 10 Mart, 11 Mart ve 22 Nisan günlerinde; $10{ }^{\circ} \mathrm{C}$ ile $20{ }^{\circ} \mathrm{C}$ aralığında, Şekil 6 ve Şekil 7' de gösterildiği gibi, 28 ve 29 Nisan günlerinde $20^{\circ} \mathrm{C}$ ile $30^{\circ} \mathrm{C}$ aralığında, Şekil $8^{\prime}$ de gösterildiği üzere, 1 Temmuz günü ise, yaklaşık olarak $30{ }^{\circ} \mathrm{C}$ ile $35^{\circ} \mathrm{C}$ aralığında değişim göstermiştir. 1 Temmuz günü, rüzgarsız bir gün olması ve yükselen hava sıcaklığı nedeniyle, PV panel gövde sicaklığı, $60{ }^{\circ} \mathrm{C}$ değerine kadar çıkabilmiştir. Diğer günlerde ise, rüzgar hızı değerine de bağlı olarak, $30{ }^{\circ} \mathrm{C}$ ile $45^{\circ} \mathrm{C}$ civarında bir değişim göstermiştir. Çalışmada, gövde sıcaklığı üzerinde etkili olan atmosferik parametrelerin, genel bir değerlendirmesi amaçlandığından, belirsizlik analizi yapılmasına gerek duyulmamıştır. Tablo 2'de PV panel gövde sicaklığının ve atmosferik parametrelerin, incelenen günlerdeki ortalama değerleri, Tablo 3 ve Şekil 9' da ise, PV panel gövde sıcaklığı için incelenen modellerle deneysel sonuçların karşılaştırılması verilmiştir.

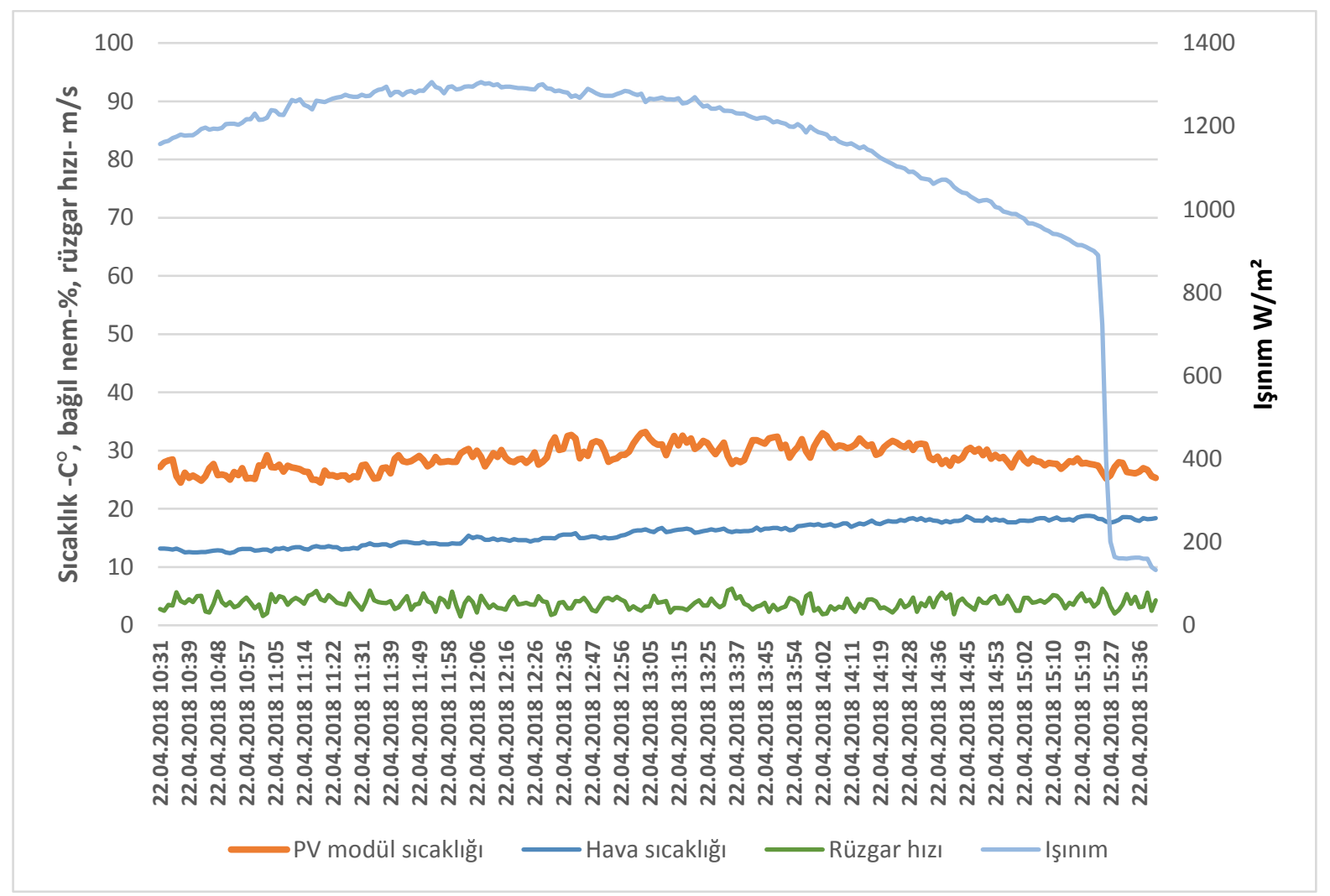

Şekil 5. 22.04.2018 tarihindeki temel parametreler. 


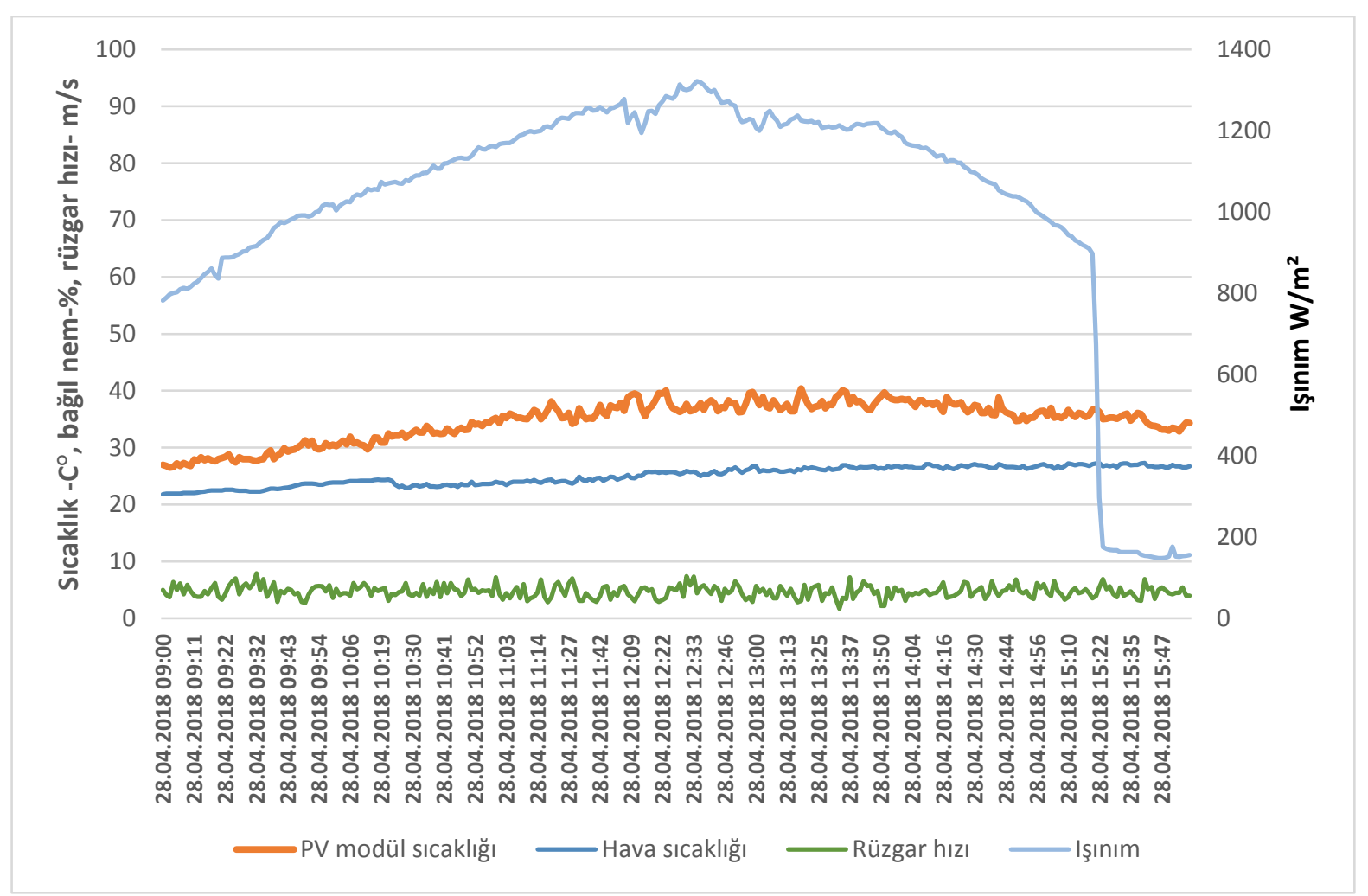

Şekil 6. 28.04.2018 tarihindeki temel parametreler.

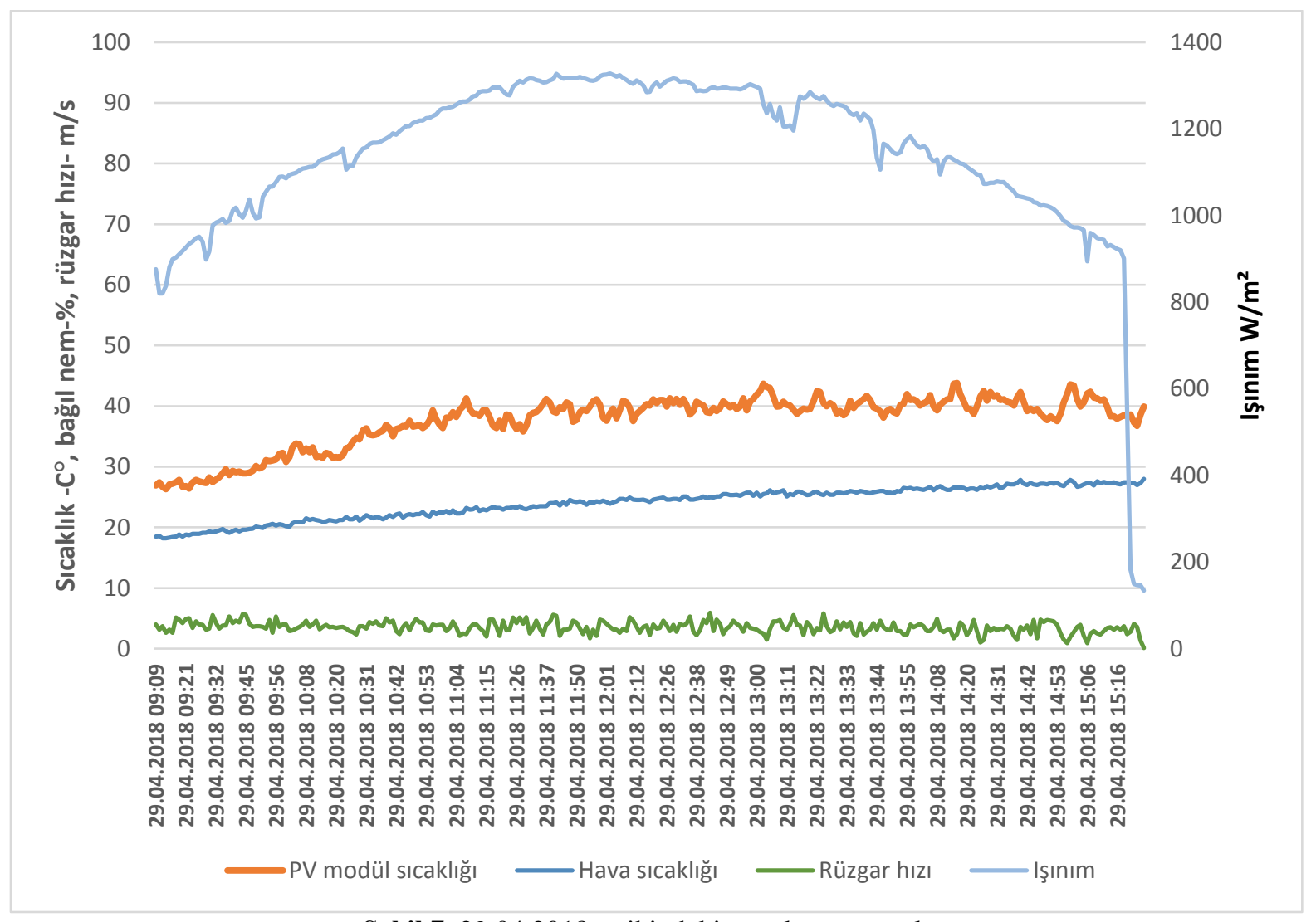

Şekil 7. 29.04.2018 tarihindeki temel parametreler. 


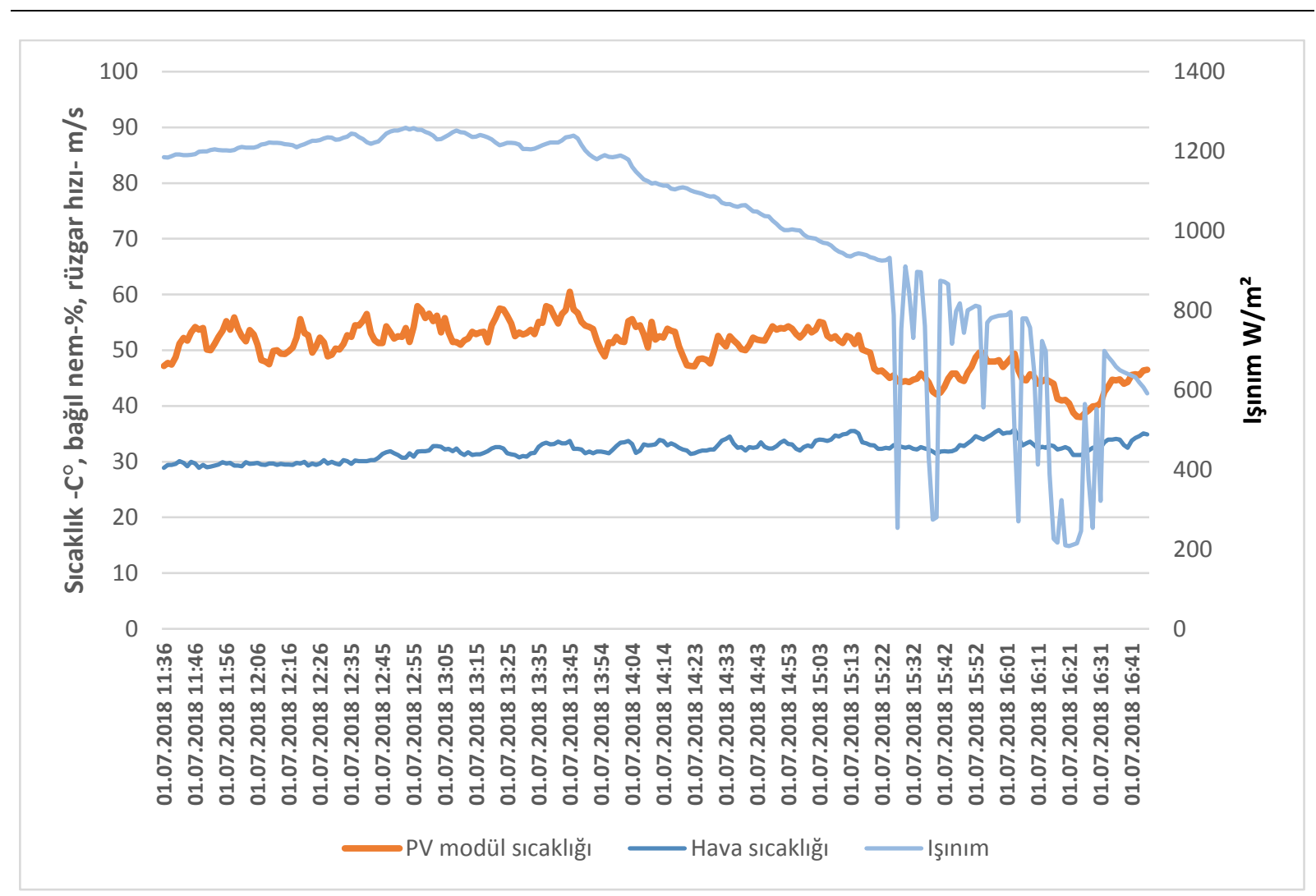

Şekil 8. 01.07.2018 tarihindeki temel parametreler.

Tablo 2. PV modül gövde sıcaklığının ve atmosferik parametrelerin incelenen günlerdeki ortalama değerleri

\begin{tabular}{|c|c|c|c|c|c|c|c|}
\hline Günler & $\mathbf{2 4 . 0 2}$ & $\mathbf{1 0 . 0 3}$ & $\mathbf{1 1 . 0 3}$ & $\mathbf{2 2 . 0 4}$ & $\mathbf{2 8 . 0 4}$ & $\mathbf{2 9 . 0 4}$ & $\mathbf{0 1 . 0 7}$ \\
\hline $\begin{array}{c}\text { Ortalama hava } \\
\text { sicaklığ } 1{ }^{\circ} \mathrm{C}\end{array}$ & 16.4892 & 16.6326 & 17.7151 & 15.7868 & 25.0518 & 23.9909 & 32.0822 \\
\hline $\begin{array}{c}\text { Ortalama güneş } \\
\text { 1şınım1 W/m }\end{array}$ & 931.5895 & 828.2019 & 1101.139 & 1133.979 & 1023.734 & 1145.293 & 1011.747 \\
\hline $\begin{array}{c}\text { Ortalama rüzgar } \\
\text { h1z1 m/s }\end{array}$ & 2.7824 & 1.2471 & 1.3756 & 3.8156 & 4.7023 & 3.5242 & 0 \\
\hline $\begin{array}{c}\text { Ortalama modül } \\
\text { sicaklığ }{ }^{\circ} \mathrm{C}\end{array}$ & 34.0351 & 33.2669 & 39.1789 & 28.7333 & 34.6609 & 37.5521 & 50.32 \\
\hline
\end{tabular}

Tablo 3. PV modül gövde sıcaklığı için incelenen modellerle deneysel sonuçların karşılaştırılması

\begin{tabular}{|c|c|c|c|}
\hline Günler & $\begin{array}{c}\text { Muzathik'in } \\
\text { çalışmasına göre } \\
\text { bulunan gövde } \\
\left.\text { sıcaklıkları [ 6 ] } \mathbf{(}^{\mathbf{0}} \mathbf{C}\right)\end{array}$ & $\begin{array}{c}\text { Lasnier ve Ang' } \\
\text { çalışmasına göre bulunan } \\
\left.\text { gövde sıcaklıkları [ 5 ] } \mathbf{(}^{\mathbf{}} \mathbf{C}\right)\end{array}$ & $\begin{array}{c}\text { Deneysel olarak } \\
\text { bulduğumuz PV modül } \\
\left.\text { gövde sıcaklıları } \mathbf{(}^{\circ} \mathbf{C}\right)\end{array}$ \\
\hline 24.02 & 29.8167 & 31.3505 & 34.0351 \\
\hline 10.03 & 30.2818 & 29.7046 & 33.2669 \\
\hline 11.03 & 36.4285 & 35.7151 & 39.1789 \\
\hline 22.04 & 31.5222 & 34.0915 & 28.7333 \\
\hline 28.04 & 36.7544 & 42.7243 & 34.6609 \\
\hline 29.04 & 39.9245 & 43.6422 & 50.3200 \\
\hline 01.07 & 50.3354 & 50.5292 & \\
\hline
\end{tabular}




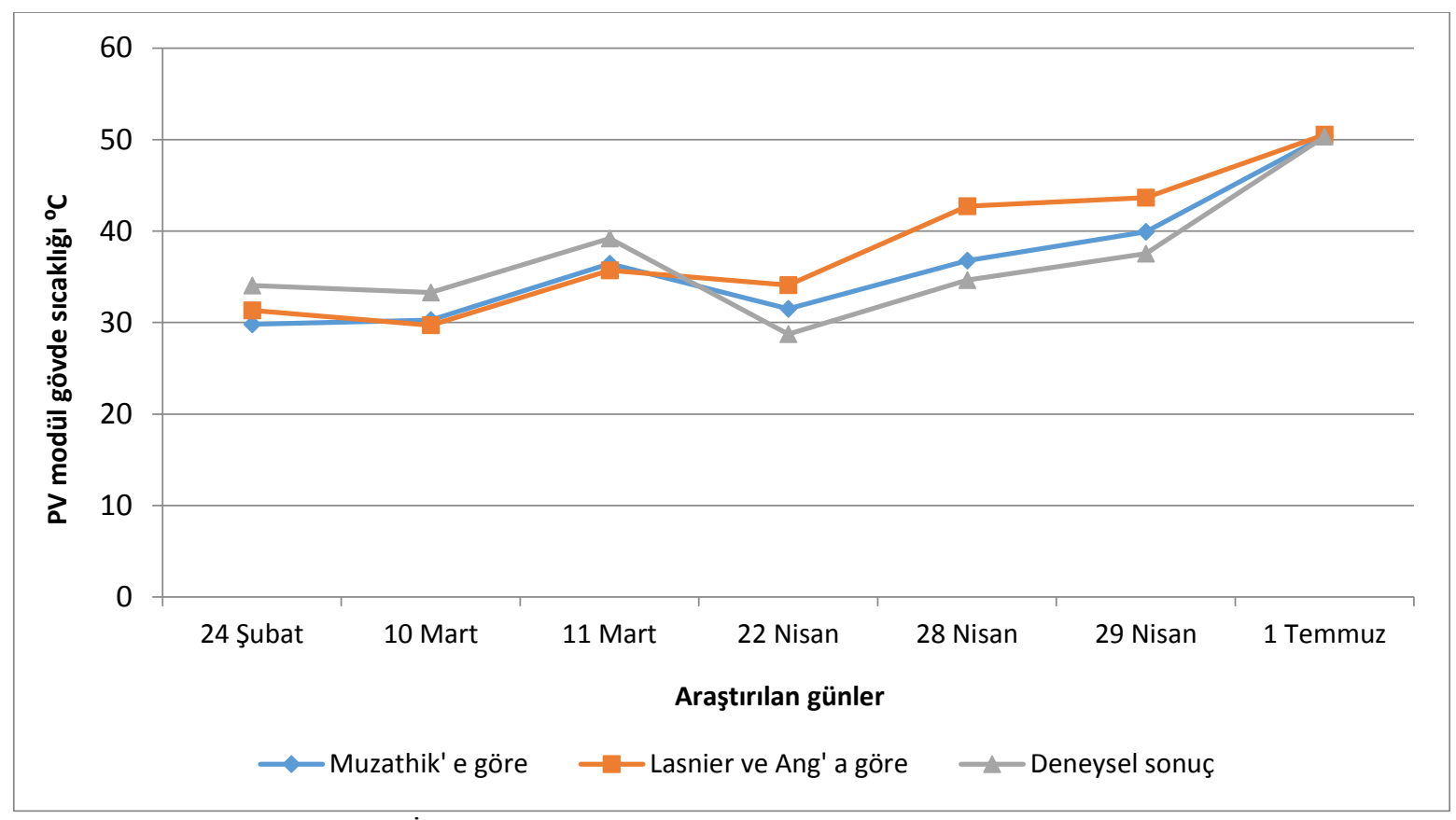

Şekil 9. İncelenen modellerle deneysel sonuçların karşılaştııılması

\section{SONUÇLAR VE TARTIŞMA \\ 4.1. Sonuç}

Çalışma sonuçları, karşılaştırma yapılan diğer iki çalışma [5,6] sonuçlarını desteklemektedir. Özellikle bu çalışma, Muzathik' in çalışmasının [6] sonuçlarını daha kuvvetli desteklemektedir. Çünkü, rüzgar hızı PV panel sıcaklığı üzerinde oldukça önemli bir faktördür. Rüzgar hızının artmasının veya azalmasının PV modül sıcaklığ 1 üzerinde doğrudan etkili olduğu tespit edilmiştir. Ayrıca PV panel sıcaklığı üzerinde diğer önemli faktörler, güneş 1şınımı ve hava sıcaklığıdır. Özellikle, güneş ışınımının anlık değişiminin, panel sıcaklığını anlık olarak etkilediği anlaşılmaktadır. Işınım miktarının arttığı anlarda PV modül sıcaklığının da arttı̆̆ı, ışınım değerinin azaldığı anlarda ise modül sıcaklıklarının da azaldığı net bir şekilde görülmüştür. Deneysel sonuçlar, güneş 1şınımı, hava sıcaklığı ve rüzgar hızının, PV panel sıcaklı̆ğ üzerinde çok önemli faktörler olduğunu göstermektedir. Özellikle, rüzgar hızı PV panel sicaklığının belirlenmesinde mutlaka hesaba katılmalıdır. Ayrıca sonuçlar, PV panelin merkezinden yapılan sıcaklık ölçümünün, panel sıcaklığını oldukça iyi temsil ettiğini göstermektedir.

\subsection{Teşekkür}

Bu çalışma, Marmara Üniversitesi Bilimsel Araştırma Projeleri Birimi tarafindan 2017 FEN-C-DRP 0703170111nolu proje ile desteklenmiştir. Deneysel çalışmalar, Konya Innopark' da gerçekleştirilmiş̧ir.

\section{KAYNAKLAR}

[1] Kalogirou S.A., Tripanagnostopoulos Y., (2006). Hybrid PV/T Solar Systems for Domestic Hot Water and Electricity Production, Energy Conversion \&Management 47, 3368-3382.
[2] Atmaca M, Pektemir I.Z., Yılmaz E., (2018). PV Panelin Altına Serbest Olarak Yerleştirilen Siyah Emici Plakanın Termal Kapasitesinin Belirlenmesi 2. Multidisipliner Çalışma Kongresi, Adana- Turkey, 4-5 Mayıs.

[3] Atmaca M, Pektemir I.Z., Yilmaz E., (2018). "Solenam" Solar Energy Absorber Machine" İsimli Yeni Bir Tasarım Sayesinde Aynı Güneş Panelinden Isıtma, Sicak $\mathrm{Su}$ ve Elektrik Elde Edilmesi Olanaklarının Araştırılması 3. Multidisipliner Çalışma Kongresi, Kiev- Ukrayna, 5-6 October.

[4] Bardhi M, Grandi G, Tina G.M., (2012). Comparison of Cell Temperature Estimation by Different Thermal Power Exchange Calculation Methods, International Conference on Renewable Energies and Power Quality

Spain, 28th to 30 th March.

[5] Lasnier F, Ang T.G., (1990) Photovoltaic engineering handbook. Adam Higler; p.258.

[6] Muzathik A.M., (2014).Photovoltaic Modules Operating Temperature Estimation Using a Simple Correlation, International Journal of Energy Engineering, 4,151-158

[7] Dubey S, Sarvaiya J.N, Seshadri B., (2013). Temperature dependent photovoltaic (PV) efficiency and its effect on PV production in The World- a review, Energy Procedia, 33,311-321

[8] Atmaca M., Pektemir İ.Z., (2019). Investigation on the effect of the total efficiency of water and air used together as a working fluid in the photovoltaik thermal systems, Processes, 7, 516. 
[9] Pektemir İ.Z., Atmaca M., (2019). PV/T Sistemlerde Termal İletken Yapıştırıcı Kullanımı Üzerine Bir Araştırma, Hezarfen Uluslararası Fen Matematik ve Mühendislik Bilimleri Kongresi, 8-10 Kasım, İzmir, Turkey.
[10] Atmaca M., Pektemir İ.Z., (2019). PV Panelinin Altına Serbest Olarak Yerleştirilen Siyah Emici Plakanın Termal Kapasitesinin Belirlenmesi, International Journal of Advances in Engineering and Pure Sciences, vol.31, pp.280-285. 